\title{
The evolution of legal controls on rhinoceros products in Hong Kong-an Asian model worth considering
}

\author{
Tom Milliken
}

\begin{abstract}
Although commercial international trade in rhinoceros parts, products and derivatives has been prohibited under the Convention on International Trade in Endangered Species of Wild Fauna and Flora since 1977, trade within national boundaries cannot be regulated under the Convention. As a result illegal trade to supply domestic markets persists and rhinoceros populations continue to decline. Hong Kong was the first government in Asia to address this problem. Over a period of 13 years Hong Kong authorities introduced regulations progressively restricting the trade until in 1989 all aspects of the country's rhino trade became subject to legal prohibitions. Hong Kong's experience offers a valuable model for other Asian countries.
\end{abstract}

\section{Introduction}

All five species of rhinoceros have been severely affected by uncontrolled poaching and illegal trade in rhino horn and today only the southern subspecies of Africa's white rhino Ceratotherium simum seems secure. In Asia, rhino horn and, to a much more limited extent, rhino hide are widely used as ingredients in traditional Oriental medicines. Rhinohorn compounds are used to treat a wide variety of ailments including rheumatism, hemiplegia, paralysis, convulsion, epilepsy, influenza, fever, rashes, ulcers, nosebleeds, insomnia, and eye diseases (But et al., 1988; Song and Milliken, 1990).

Since 1977, all rhino species have been listed on Appendix 1 of the Convention on International Trade in Endangered Species of Wild Fauna and Flora (CITES), which prohibits commercial international trade in all rhinoceros parts, derivatives, or products. Control of domestic possession and sale of rhino parts and products, however, is beyond the specific mandate of CITES and remains unregulated in most consuming countries in Asia. As a result, most rhino horn markets remain active, illegal trade to supply them persists, and many rhino populations continue to suffer serious declines.

At the sixth meeting of the Conference of the Parties to CITES in 1987, a special resolution was passed explicitly recognizing that CITES controls had failed to stem the flow of illegal trade in rhinoceros parts and products. CITES Resolution Conf. 6.10 (Trade in Rhinoceros Products) urged all Parties to take exceptional measures to effect 'a complete prohibition on all (sic) sales and trade, internal and international, of rhinoceros parts and derivatives, especially horn, whether whole or in any other form, including personal effects'. The only exemption provided in the resolution was for the 'non-commercial movement of legitimate hunting trophies'.

Authorities in Hong Kong, a British Territory on the south-west coast of China, have successfully addressed this issue to become the first government in Asia to completely ban all aspects of international and internal trade in rhinoceros products. While the first regulatory steps commenced in 1978 (2 years after CITES entered into force in the Territory), Hong Kong's policy has steadily evolved over the last decade into the strictest and most thorough control system in Asia. 
Consequently, Hong Kong's policy serves as a useful model for other countries striving to control trade in rhinoceros products. This report presents the progressive actions authorities took in arriving at a complete ban on rhinoceros products and discusses the key elements in Hong Kong's policy that should be adopted in efforts elsewhere.

\section{Registration of rhino horn and hide and the introduction of possession licences}

The first step in Hong Kong's control policy for rhino products was the introduction of possession licences in 1976 under the Animals and Plants (Protection of Endangered Species) Ordinance, Cap. 187. In 1976, 'Rhinoceros Species' and their horns became subject to possession licences under the Ordinance, but this requirement was interpreted to cover only the Javan and Indian rhinos, the two species in the genus Rhinoceros, but not black, white, or Sumatran rhinos of the monotypic genera Diceros, Ceratotherium and Dicerorhinus, respectively. The scope of the law was extended in 1978 to cover all Rhinocerotidae species and to also include rhino hide as a controlled substance requiring a possession licence. All companies or individuals possessing raw and simply prepared rhino horn or hide were obliged to file an Application for a Licence to Import/Possess with the Agriculture and Fisheries Department (AFD), Hong Kong's CITES Management Authority.

The Ordinance allowed a period of 3 months for this registration to take place and the government publicized the requirement through announcements in the local media. In processing each application, teams of AFD personnel verified the reported stocks before possession licences were officially issued. Physical marking of registered stocks was not required in recognition of the fact that such marks would most likely disappear as the horn was shaved or ground into powder during consumption. When the registration was completed in early 1979, possession licences had been issued to six individuals or companies covering a total of $696 \mathrm{~kg}$ of rhino horn and $1825 \mathrm{~kg}$ of rhino hide.

Under Hong Kong law, these stocks qualified for the pre-Convention exemption allowed under Article VII of CITES and were eligible for re-export. Internal sale and consumption was also allowed but, with the exception of direct sales to consumers at the retail level, the transferral of rhino horn or hide could only transpire under the possession licence system. Individuals or companies holding possession licences were obliged under the licence conditions to report to AFD changes in their stocks and AFD would amend the possession licences as appropriate. The AFD's law enforcement and monitoring activities included periodic inspection visits, some of which were unannounced, to ensure that dealers were complying with system.

\section{Introduction of import and export bans on rhino horn and hide}

In February 1979, following the rhino horn and hide registration, Hong Kong authorities established a ban on any further commercial importation of rhino parts and derivatives, even if they qualified for a pre-Convention exemption under CITES. This move effectively limited the legal supply of rhino horn and hide in Hong Kong to those stocks that had been registered by AFD. The government urged traders to dispose of their registered stocks through local consumption or re-export to other rhino horn consumers abroad. The issuance of re-export permits was subject to the presentation of possession licences, which were then amended to reflect the reduction of stocks. Between January 1979 and December 1984 , a total of $64 \mathrm{~kg}$ of horn (but no hide) was legally re-exported from Hong Kong as preConvention stocks.

In early 1985, the government issued a circular letter to inform those in possession of rhino horn and hide that international pressure was building on Hong Kong to impose further controls on the trade in rhino parts. Traders were advised to dispose of remaining stocks as soon as possible. With reference to the fact that no official exports had occurred 
since September 1984, the government notified dealers in October 1985 that a total reexport ban on pre-Convention rhino horn and hide stocks was slated to take effect 1 April 1986. From 1985 until the re-export ban took effect, another $0.6 \mathrm{~kg}$ of horn (but no hide) was legally re-exported from Hong Kong. Once the ban took effect, all legal international trade from Hong Kong ceased, although rhino horn or hide could still be traded and consumed locally.

\section{Introduction of possession licences for rhino horn carvings, antiques and trophies}

The adoption of CITES Resolution Conf. 6.10, in 1987, provided the impetus for Hong Kong authorities to take further measures to control the possession of rhinoceros products other than horn or hide, including personal effects. In the local media and through a circular letter to relevant traders, AFD publicized impending legal changes that would require the registration of 'all products of rhinoceros'. Effective in August 1988, administrative interpretation of this requirement extended the need for possession licences to all rhino carvings, antiques and trophies, including personal effects, but did not include manufactured medicines that use rhinoceros substances as ingredients, (which was addressed as a separate issue later on). This measure closed a potential loophole in the control system and made all readily recognizable rhino horn items subject to a possession licence. A total of 93 possession licences was issued in 1988, all for antique horn carvings.

\section{Ban on internal transfer or sale of rhino horn and hide}

As early as February 1987, AFD warned dealers that a ban on all aspects of domestic trade of registered rhino parts may follow decisions taken at the sixth meeting of the Conference of the Parties to CITES. In view of the fact that Hong Kong's registered rhino horn stocks had dwindled from $40 \mathrm{~kg}$ in December 1987 to 3.8 $\mathrm{kg}$ in March 1988, the government moved to limit further the scope of domestic trade. After a series of meetings with Oriental trade association members, AFD imposed administrative measures, which froze possession of registered rhino stocks. Effective 1 August 1988, all possession licences carried the following terms: 'The specimen(s) must not be transferred or sold to any person in Hong Kong or elsewhere'. As a result, all over-the-counter sales in Oriental medicine shops in Hong Kong ceased, but, in fact, this development caused little difficulty for local dealers as, with the exception of personal antiques, by November 1988, all registered rhino horn in Hong Kong had been consumed. Currently only $11.4 \mathrm{~kg}$ of rhino hide remains under possession licence in the Territory under the terms stipulated above.

\section{Ban on import, export, and local sale of medicinal products claiming to contain rhinoceros ingredients}

In spite of the evolving legal controls imposed on the possession of and trade in rhino parts in Hong Kong, manufactured medicines remained outside of the control framework for two reasons. First, manufactured Oriental medicines have never been subject to legal controls in Hong Kong, and secondly, as CITES only covers readily recognizable parts and derivatives, rhinoceros ingredients in manufactured products are rarely, if ever, in a readily recognizable form.

With the adoption of CITES Resolution Conf. 6.10 in 1987, however, Hong Kong authorities were forced to address this issue. In order to legally regulate manufactured medicinal products that purport to contain rhinoceros ingredients, it became necessary to amend the Animals and Plants (Protection of Endangered Species) Ordinance, Cap. 187. In May 1988, AFD notified Oriental medicine dealers of the government's intention to introduce amendments that would prohibit the import, export, possession and local sale of all products claiming to contain rhinoceros ingre- 
dients and urged dealers to dispose of existing stocks as soon as possible. The draft amendments were published in the Government Gazette in May 1989 for presentation in Hong Kong's Legislative Council.

Because many of the medicines were produced in China and imported into the Territory, it became necessary for Hong Kong dealers to notify their suppliers of the ensuing legal crackdown on products with rhinoceros ingredients. Manufacturers abroad were urged to substitute alternative substances and to eliminate any reference to rhinoceros parts and derivatives on the packaging of their products. When the legal amendments finally took effect on 1 December 1989, all aspects of Hong Kong's rhino trade became subject to legal prohibitions.

\section{Law enforcement}

In conjunction with the evolving legal framework to control trade in rhinoceros parts and products, Hong Kong authorities pursued a variety of wide-ranging law enforcement activities. Periodic inspections of dealers' stock and other monitoring activities were undertaken with respect to the dispensation of registered stocks. On other fronts, Customs officers worked to prevent illegal traffic in rhinoceros parts and derivatives from entering or passing though the Territory. Following the ban on re-export of rhino horn, between April 1986 and December 1988, a total of $110.8 \mathrm{~kg}$ of rhino horn was confiscated by Hong Kong authorities.

Since then, instances of illegal trade have continued to surface. In February 1989, Customs seized 18 rhino horns weighing 25.4 $\mathrm{kg}$ in the process of being illegally imported from South Africa. Three more horns, weighing a total of $5 \mathrm{~kg}$, were confiscated entering the Territory from the United Arab Emirates in July 1989. And finally, in September 1989, 14 horns weighing $20 \mathrm{~kg}$, apparently in transit from Singapore to Macau, were seized by Hong Kong authorities.

It is also important to note that Hong Kong moved to strengthen the penal code under the
Animals \& Plants (Protection of Endangered Species) (Amendment) Bill of 1989. As a result, maximum penalties for violations of import, export, or possession restrictions for scheduled species (which include all parts, derivatives, and products of rhinoceros species, including medicines) were increased to $\$ H K 25000$ (\$US3250) and \$HK50,000 (\$US6500), for first time or repeat offenders, respectively.

\section{Discussion and conclusions}

Hong Kong's experience in establishing a comprehensive control policy for rhinoceros products contains several key elements, which need to be addressed by all countries striving to curtail an import demand and internal trade. These include the following:

(1) Broad legal scope to deal with all rhinoceros commodities. Domestic control policies must ultimately address the full range of rhinoceros products and commodities available in local markets. Although regulations may be varied depending on the commodity or particular circumstances, legal controls need to exert authority over: raw or simply prepared rhinoceros parts and derivatives, including those dispensed through over-the-counter sales; manufactured products, especially Oriental medicines that contain, or purport to contain, rhinoceros ingredients; and rhinohorn antiques, carvings and trophies, including personal effects.

(2) Registration of stocks and issuance of possession licences. A legally mandated registration of all raw rhino horn, including pieces, shavings and powder, and perhaps rhino-hide, should be conducted under the auspices of a competent government authority. Registration should also be extended to include personal effects, such as rhino-horn carvings, antiques, and trophies, where circumstances warrant such action. Registered stocks need to be verified by government personnel and subsequent possession linked to an officially issued licence, which can be amended as necessary to reflect the disposal of stocks.

Registration under licence is probably the 
single most critical step in asserting domestic controls. First, it allows the government to identify each individual and company holding stocks of rhino horn or hide and to define the scale of the issue. Secondly, it provides the basis to monitor the subsequent dispensation of registered stocks, particularly if those holding possession licences are obliged to file regular stock inventory reports with government. Thirdly, in conjunction with effective monitoring and law enforcement efforts, it prevents the undetected introduction of new stocks of rhino horn into the country. And finally, it provides the legal basis for seizure and confiscation of stocks that remain unlicensed.

(3) Import and export/re-export bans. Prior to or in conjunction with registration of domestic stocks, it is essential to ban any further commercial importation of rhinoceros parts and derivatives, even in cases where CITES exemptions may allow trade (i.e. preConvention rhino horn). The ultimate goal of registration is to establish the means, in terms of monitoring and law enforcement, for the orderly disposal of existing stocks so that their domestic sale can eventually be prohibited. Adding to the registered stockpile through continued importation will only serve to prolong and complicate the situation.

Although Hong Kong policy makers were fortunate to have had a reasonably long period of time in which to develop their poli$c y$, and the re-export of registered rhino stocks remained an option for several years, the current international situation is not favourable to this approach. Virtually all countries known to consume rhino horn currently prohibit importation, either as Parties to the Convention or through national legislation. Moreover, CITES Resolution Conf. 6.10 calls for a complete prohibition on all commercial international trade. Therefore, it is reasonable to argue that export bans on rhino parts and derivatives should be introduced early on in conjunction with bans on future importation with the understanding that disposal of registered stocks should be limited to domestic consumption.

(4) Total ban on domestic trade. Finally, it is important to establish a cut-off date, at which point any further allowance of domestic dis- play and sale of registered rhinoceros parts, derivatives and products, including Oriental medicines that purport to contain rhinoceros ingredients, is prohibited (except, perhaps, bona fide antique carvings). In most countries, both legal and practical concerns make it necessary to provide an interim policy for the orderly disposal of registered stocks before all aspects of commercial domestic trade are terminated. Efforts should be made to direct Oriental medicine dealers to substitutes. The cut-off date needs to be carefully considered in view of domestic circumstances, but, ideally, should not exceed 3 years given the intense pressure most species of rhinoceros are facing. During this period regular monitoring is necessary to ensure that disposal of stocks proceeds in accordance with established laws and policy. Once the cut-off date arrives, all possession licences for commercial stocks need to be frozen and existing stocks forfeited to the state or held under special licence agreements that preclude any further commercial activity.

(5) Penalties for offenders. It is also necessary for government authorities to structure specific sanctions for violators into the legal framework for control of importation, exportation, domestic sale or offer for sale, and possession of rhino parts and products. These penalties should be strong enough to serve as effective deterrents to potential offenders. Ideally, penalties should be commensurate with the retail value of the commodity itself.

Asia's domestic trade in rhinoceros parts and products continues to subvert most conservation efforts for rhinoceros species. It is hoped that in more countries where traditional Oriental medicine practices continue to thrive, comprehensive legal control policies similar to Hong Kong's will be imposed. Clinical verification of the efficacy of rhino horn substitutes, especially saiga antelope horn, has been documented in recent studies undertaken in Hong Kong and elsewhere (But et al., 1988; But et al., 1990). These results provide a clear justification for government authorities to move against rhino-horn usage, while still preserving fundamental Oriental medicine traditions.

China remains the world's largest manufac- 
turer of rhino-horn medicines. In 1989, a government registration of rhino-horn stockpiles found $15 \mathrm{import} /$ export corporations and an undisclosed number of manufacturers in possession of $9874.8 \mathrm{~kg}$ (Martin, 1990). The registration, however, did not cover rhino-horn stocks in retail medicine shops, museums, or private ownership. Moreover, it seems likely that many factories failed to declare their stocks. A recent analysis by TRAFFIC of a Chinese government report on traditional medicine products identified 29 rhino-horn medicines currently being manufactured at 121 different factories located in 27 of the country's 28 administrative districts.

Since the end of 1988, export regulations have stipulated that CITES permits are required for commercial consignments of rhino-horn medicines; in fact, these measures have done little to inhibit the flow of such medicines abroad. China's control policy for rhinoceros parts and products remains at a rudimentary stage and is crippled by acute law enforcement problems.

The government of Taiwan, a non-Party to the Convention, also completed a legally-mandated registration of rhino horn in November 1990 which ostensibly covered all importers, wholesalers, retailers, and private owners; a total of 410 registrants declared stocks totalling $1464.5 \mathrm{~kg}$ (Milliken et al., 1991). However, a comprehensive TRAFFIC survey in early 1991 confirmed rhino horn availability at over 1800 traditional pharmacies throughout the island and minimally estimated Taiwan's current stockpile at $3712 \mathrm{~kg}$ and possibly as high as $8943 \mathrm{~kg}$ (Nowell et al., 1991). Clearly, Taiwanese authorities face a significant law-enforcement challenge to current regulatory efforts and a coherent future control policy still needs to be promulgated.

Authorities in South Korea, another nonParty and major market for over-the-counter dispensation of rhino-horn medicines, seem reluctant to exert controls over domestic sales in the near future, although TRAFFIC has lobbied key government ministries to undertake registration since early 1990 (Milliken, 1991). While the use of rhino horn in commercially manufactured medicines has been prohibited since 1983, its use in at least 16 popular medicines produced on demand at the thousands of Oriental medicine clinics throughout the country remains completely unregulated and there are no reliable estimates concerning current rhino-horn stockpiles in the country (Song and Milliken, 1990).

And finally, a number of South East Asian countries, most notably Thailand, Malaysia, Singapore and Indonesia, generally fail to control both over-the-counter sales of rhino parts or traffic in rhino-horn medicines manufactured in China. Again, the amount of rhino horn remaining in these countries is unknown. Without specific policy action on the part of Asia's major rhino-horn-consuming countries, it may not be an exaggeration to say that efforts to save most remaining populations of rhinos are doomed to certain failure.

\section{Acknowledgments}

The author would like to extend sincere thanks to Mr M. K. Cheung and Mr P. K. Chan of the Agriculture and Fisheries Department of Hong Kong for their co-operation with this analysis.

\section{References}

But, P.P., Lung, L. and Tam, Y. 1988. Profiles of Chinese medicines, 4. Rhinoceros horn. Abstracts of Chinese Medicines, 2, 351-360.

But, P.P., Lung, L. and Tam, Y. 1990. Ethnopharmacology of rhinoceros horn. I. Antipyretic effects of rhinoceros horn and other animal horns. Journal of Ethnopharmacology, 30, 157-168.

Martin, E.B. 1990. Medicines from Chinese treasures. Pachyderm, 13, 12-13.

Milliken, T. 1991. South Korea revisited: the trade in rhino horn and ivory. Pachyderm (in press).

Milliken, T., Martin, E.B. and Nowell, K. 1991. Rhino horn trade controls in East Asia. TRAFFIC Bulletin, (in press).

Nowell, K., Chyi, W.W.L. and Pei, K.C.J. In press. The horns of dilemma: the market for rhino horn in Taiwan. TRAFFIC Bulletin.

Song, C. and Milliken, T. 1990. The rhino horn trade in South Korea: still cause for concern. Pachyderm, 13, 5-11.

Tom Milliken, TRAFFIC Japan, 7th Floor Nihonseimei Akabanebashi Bldg., 3-1-14 Shiba, Minato-ku, Tokyo 105 Japan. 